\title{
Changes in Cortical $\beta$-Adrenergic Receptor Density and Neuronal Sensitivity to Norepinephrine Accompany Morphine Dependence and Withdrawal
}

\author{
HYLAN C MOISES ${ }^{1}$ and CHARLES B SMITH² \\ Departments of 'Phystology and 'Pharmacology. Universtty of Michigan, Ann Arbor, MI 48109 (USA) \\ (Accepted 20 May 1986)
}

Key words $\beta$-Adrenergic receptor - Supersensıtıvity - Norepınephrıne - Morphıne dependence - Withdrawal Parietal cortex - Receptor binding - Microiontophoresis

\begin{abstract}
Radioligand binding experiments were carried out in conjunction with electrophysiological recordings in vivo in the parietal cortex in rats to assess changes in postsynaptic $\beta$-adrenergic receptor function that result after chronic administration of morphine and during morphine withdrawal Chronic treatment of rats with morphine for 14 days resulted in a $38 \%$ increase in the density of $\beta$-adrenergic receptors in the parietal cortex. as measured by the bindıng of the specific antagonist $\left[{ }^{3} \mathrm{H}\right]$ dihydroalprenolol (DHA) In comparison, following withdrawal in the chronic morphine-treated anımals, the number of specific $\left[{ }^{3} \mathrm{H}\right] \mathrm{DHA}$ binding sites in this same cortical region was decreased $25 \%$, when compared to salıne-treated controls These alterations in cortical $\beta$-adrenergic receptor density were not accompanied by a significant change in the dissociation constant $\left(K_{\mathrm{d}}\right)$ for $\left[{ }^{3} \mathrm{H}\right] \mathrm{DHA}$ or in the inhibitory constants $\left(K_{1}\right)$ for the specific agonists norepinephrine and ssoproterenol Microiontophoretic testing revealed that the changes in $\beta$-adrenergic receptor density found in parietal cortex after chronic morphine treatment and during morphine withdrawal were accompanied by a selective increase and decrease, respectively, in the sensitivity of cerebrocortical neurons in the same region to $\beta$-adrenergic stımulation These results suggest that changes in central adrenergic function might be related to the formation and/or expression of dependence on morphıne
\end{abstract}

\section{INTRODUCTION}

Evidence from both experimental and clinical studies indicates that central noradrenergic mechanısms may play an important role in the formation and/or mediation of opiate withdrawal. For example, depletion of norepinephrine (NE) levels in brain prior to the precipitation of withdrawal has been shown to reduce the intensity of the withdrawal syndrome in morphine-dependent rats $^{4,10}$, whereas a marked potentiation of withdrawal intensity has been observed following administration of agents known to augment central noradrenergic actıvity ${ }^{10}$. In addıtion, Redmond et al ${ }^{29}$ have shown that in subhuman primates direct stımulation of the locus coeruleus (LC) elicits a profile of behavioral and physiological effects strikingly sımilar to those observed durıng oprate withdrawal. Both morphine and the $\alpha_{2}$ adrenergic agonıst clonidine have been shown to block these effects of LC activation ${ }^{30}$ and to suppress the acceleration in LC neuron firıng and NE turnover in brain that occur during acute opiate withdrawal ${ }^{1,32}$ Clonıdine has also been shown to alleviate opiate withdrawal symptoms in animals and $\operatorname{man}^{8.30}$; an effect which has been attributed in large part to its inhibitory influence on LC noradrenergic neuronal activity These data have led some workers to suggest that increased activity of central noradrenergic neurons, particularly those of the LC, may account for significant components of the opiate withdrawal syndrome

Other data suggest that alterations in adrenergic receptors on LC target cells may contribute to or reinforce the effects occurring in the opiate-sensitive noradrenergic neurons. Several laboratories have reported an increase in $\beta$-adrenergic receptor density, as measured by the binding of the selective antagonist $\left[{ }^{3} \mathrm{H}\right]$ dihydroalprenolol $\left(\left[{ }^{3} \mathrm{H}\right] \mathrm{DHA}\right)$, in areas such

Correspondence H C Moıses, Department of Physiology, Unıversity of Michigan, Ann Arbor, MI 48109, U S A 
as the cerebral cortex, hippocampus and brainstem in rats treated chronically with morphine $e^{9,17,24}$. An increase in the number of $\beta$-adrenergic receptors labelled with $\left[{ }^{3} \mathrm{H}\right]$ DHA has also been observed in the iris of rat pups made dependent on morphine ${ }^{20}$. On the other hand, Kuriyama et al. ${ }^{15}$ reported that the number of specific binding sites for $\left[{ }^{3} \mathrm{H}\right] \mathrm{DHA}$ was unchanged in whole brain or cerebral cortex in morphine-dependent rats, but increased abruptly following precipitation of withdrawal in the dependent animals by naloxone. It was further shown that the abrupt increase in $\left[{ }^{3} \mathrm{H}\right] \mathrm{DHA}$ binding found in the cortex during withdrawal was due mainly to an increase in the density of $\beta_{1}$-type adrenergic receptors $^{13}$. Much evidence indicates that the effects of the LC input to rat cortex are mediated via $\beta_{1}$-type adrenergic receptors which, for the most part, are located postsynaptically on cerebrocortical neurons $^{22,23}$. Accordingly, it would be important to determine whether the alterations in cortical $\beta$-receptor density that have been reported after chronic morphine treatment or withdrawal result in a corresponding hypersensitivity of these same neuronal elements to noradrenergic stimulation. The functional correlates of the changes in cortical $\beta$-adrenergic receptor density that have been observed in both dependent and withdrawn animals have yet to be assessed at the single neuron level.

Neurons within the parretal cortex in rat are known to receive a prominent innervation of noradrenergic fibers from the $\mathrm{LC}^{25,37}$, and are inhibited by $\mathrm{NE}$ acting postsynaptically via a $\beta$-adrenergic receptor $^{2.3 .27}$. In addition, changes in $\beta$-adrenergic receptor density have been reported in this brain region in chronic morphine-treated rats $^{24}$. In the present study, radioligand bindıng experiments were carried out in the parietal cortex in conjunction with in vivo microiontophoretic testıng of drugs to determine whether changes in $\beta$-adrenergic receptor density that result from chronic morphine treatment are reflected in corresponding alterations in postsynaptic sensitivity of cerebrocortical neurons to NE. Experiments were carried out at early and late tımes following withdrawal of chronic morphine treatment to assess the possible relationship of changes in $\operatorname{cortical} \beta$ adrenergic receptor function to the abstinence syndrome. Some of this work has been reported previously in preliminary form ${ }^{24}$.

\section{MATERIALS AND METHODS}

\section{Preparation of animals}

Male Sprague-Dawley rats, werghing 170-225 g at the start of this study, were used. Animals were housed in groups of 6 and allowed free access to food and water. Sixty-two animals were used in the electrophysiological experiments and more than 120 anımals in the binding studies. All animals withın the experimental groups received an identical regimen of chronic morphine treatments. However, in order to maintain uniform sampling times following drug treatment and avoid possible confounding effects of anesthesia associated with the electrophysiological testing, different animals were used for the receptor binding and recording experiments. Morphine tolerance and dependence were induced and maintained by givıng repeated i.p. injectıons of morphıne sulfate every $8 \mathrm{~h}$ for 14 days. The dosage of narcotic ranged from $10 \mathrm{mg} / \mathrm{kg} 3$ times a day (t.i d.), on the first day, being doubled after every third day, to $100 \mathrm{mg} / \mathrm{kg}$, t.i.d., on the last two days. Control animals were given i.p. injections of saline according to the same treatment schedule. At the end of the treatment schedule some rats from the morphine and saline treatment groups were challenged with naloxone 1 $\mathrm{mg} / \mathrm{kg}$, s.c. to assess the development of dependence on the oprate. These animals were not used in the receptor binding or electrophysiological studies.

\section{Radioligand binding studies}

Rats were killed by decapitation either $8 \mathrm{~h}$ (these animals constituted the opiate-dependent group) or $32 \mathrm{~h}$ (for the withdrawal group) after the last drug injection and their brains removed. The brains were dissected and the parietal cortices isolated from 6 rats pooled for each experiment. The brain tissues were homogenized in $5 \mathrm{ml}$ of ice-cold Tris-sucrose buffer ( $5 \mathrm{mM}$ Tris(hydroxymethyl)aminomethane, $0.25 \mathrm{M}$ sucrose) adjusted to $\mathrm{pH}$ 8.0. The homogenates were centrifuged at $1000 \mathrm{~g}$ for $10 \mathrm{~min}$ and the supernatants saved and recentrifuged at $40,000 \mathrm{~g}$ for $10 \mathrm{~min}$. The crude membrane pellet was washed twice with icecold Tris-incubation buffer and recentrifuged for 10 $\min$ at $40,000 \mathrm{~g}$. The final membrane pellet was resuspended in Tris-incubation buffer which consisted of $50 \mathrm{mM}$ Tris(hydroxymethyl)aminomethane adjusted to $\mathrm{pH}$ 8.0. 
To measure $\beta$-adrenergic receptor density. I-ml aliquots of the neural membranes were incubated in duplicate for $30 \mathrm{~min}$ at $25^{\circ} \mathrm{C}$ with various concentrations of $\left[{ }^{3} \mathrm{H}\right] \mathrm{DHA}$ (spec. act., $341 \mathrm{Cl} / \mathrm{mmol}, \mathrm{N}$ E.N . Boston, MA). Non-specific bindıng was determıned by addition of unlabeled propranolol $10^{-5} \mathrm{M}$ to a second pair of incubates. Specific, 1 e. receptor, binding was defined as the difference between total $\left[{ }^{3} \mathrm{H}\right] \mathrm{DHA}$ bound in the absence and presence of propranolol and ranged from $85.7 \pm 23 \%$ at a ligand concentration of $0.1 \mathrm{nM}$ to $70.9 \pm 244^{\circ} \mathrm{c}$ at a concentration of $6.4 \mathrm{nM}$ Specific binding was $88.3 \pm 12 \%$ at ligand concentrations of both $0.8 \mathrm{nM}$ and $16 \mathrm{nM}$ which were in the range of the $K_{\mathrm{d}}$. Incubations were termınated by rapid filtration under vacuum through Whatman GF/C glass fiber filters and by washing with two 10-ml alıquots of Tris-incubation buffer $\left(25^{\circ} \mathrm{C}\right)$. After air drying, the filters were placed in scintillation vials and counted for radioactivity at $35 \%$ efficiency

Saturation experıments were conducted at 9 concentrations of $\left[{ }^{3} \mathrm{H}\right] \mathrm{DHA}(0.1-256 \mathrm{nM})$. Prelimınary estımates of the maximum number of binding sites $\left(B_{\max }\right)$ and dissociation constants $\left(K_{\mathrm{d}}\right)$ for $\left[{ }^{3} \mathrm{H}\right] \mathrm{DHA}$ were determined by use of the computer program EBDA $^{21}$ Final values were calculated by the non-linear regression program LIGAND, devised by Munson and Rodbard ${ }^{26}$ Hill plots were also generated from the computer analysis to determine the presence or absence of receptor cooperatıvity For displacement studies, $\mathrm{IC}_{50}$ ) s were estimated by an iterative curve fittıng program described by Parker and Waud $^{28}$, and the inhibitory constants $\left(K_{1}\right)$ for NE and isoproterenol (ISO) were calculated by use of the formula of Cheng and Prusoff ${ }^{6}$ Protein was determined by the method of Lowry et al. ${ }^{18}$ using bovine albumin as standard Results are expressed as femtomoles of $\left[{ }^{3} \mathrm{H}\right]$ DHA specifically bound per milligram of protein. Values given in the text are means $\pm S E M$ of the number of experıments shown in parentheses Data were assessed statistically by means of twotarled Student's $t$-test and analysis of variance

\section{Extracellular recording and microlontophoresis}

Fifty-four of the anımals studied electrophysiologıcally were mantained under halothane anesthesia. In 8 additional experiments, a decerebrate. unanesthetized preparation was used to control for possible confounding effects of anesthesia on central norddrenergic actıvity and endogenous opiold function Rats were anesthetized initially with halothane ( $2.5 \%$ in air), intubated and mounted in a stereotaxic frame. The respiratory anesthetic was then either lowered to $0.75 \%$ and mantained at that level throughout the experiment or held constant while a surgical transection of the brainstem was performed at a level just anterior to the LC Low cerveau-isolé transections were performed according to procedures described by Wang and Aghajanian ${ }^{\text {it }}$ usıng a retractable wire knife. After transection, halothane anesthesia was discontinued to these animals Wound edges and pressure points in both preparations were infiltrated with a solution of $2^{2} c$ procaine hydrochloride (Abbot Labs.) on a regular basıs Core temperature of the animals was mantained at $37^{\circ} \mathrm{C}$ by means of a servo-control temperature regulatıng device

A tandem animal protocol, similar to that described by Schultz et al. ${ }^{34}$. was employed for testing neuronal sensitivity to microiontophoretically applied agonists. Briefly, a coded control anımal and a coded morphıne-treated or morphıne-withdrawn anımal were prepared concurrently and placed in separate stereotaxic frames on the recording table Both anımals were usually prepared for recording by someone other than the experimenter in order to carry out the sensitivity testing in a single-blind fashion. mınımızıng experımenter bias. A midlıne incision was made in the scalp and a cranıotomy performed to expose a circumscribed portion of the parietal cortex. extending 2-5 $\mathrm{mm}$ lateral from the midline and $1 \mathrm{~mm}$ anterior to $3 \mathrm{~mm}$ posterior of bregma (see $\mathrm{Fig} 2 \mathrm{~A}$ ). After removal of the dura, the exposed pral surface was covered with ungelled agar in balanced salt solution

Five- and seven-barreled glass micropıpettes (3-5 $u$ m diameter tips) were used to record extracellularly from single cerebrocortical neurons and to apply drugs at the recording site by microiontophoresis. Recording barrels were filled with $4 \mathrm{M} \mathrm{NaCl}$ or a solutıon of $2 \mathrm{M} \mathrm{NaCl}$ saturated with Fast green dye and had in vitro impedances of 3-8 M $\Omega$. Drug barrels were backfilled with freshly prepared solutions of (-)-NE-HCl 05 M, pH 4.5 (Sigma); (-)-1soproterenol bitartrate $0.25 \mathrm{M}$, pH 48 (Sigma); (+)-isoproterenol bitartrate $025 \mathrm{M}, \mathrm{pH}+8$ (Sigma), sotalol hy- 
drochloride $0.25 \mathrm{M}, \mathrm{pH} 4.5$ (Regis Chemical); phentolamine mesylate $0.25 \mathrm{M}, \mathrm{pH} 4.8$ (Ciba-Geigy); or $\gamma$-aminobutyric acid (GABA) $0.1 \mathrm{M}, \mathrm{pH} 3.5$ (Sigma). Drug solutions were ejected as cations or retained by application of $15 \mathrm{nA}$ currents of opposite polarity Automatic current balancing was maintained through an additional peripheral barrel containıng $3 \mathrm{M} \mathrm{NaCl}$. Positive and negative currents were independently passed through this barrel to check for possible current artifacts.

For these experıments, recording of neuronal activity was confined to a uniform $3 \times 4 \mathrm{~mm}$ area of tissue withın the sensorimotor region of the parietal cortex. This same area of cortex comprised a significant portion of the tissue used in biochemical determinations of $\left[{ }^{3} \mathrm{H}\right] \mathrm{DHA}$ bınding to cortical $\beta$-adrenergic receptors Because this area of cortex contains a heterogeneous population of neurons, cells were first tested for their responsiveness to peripheral tactıle stımulation in order to define a relatıvely uniform population of test neurons. Only those units which responded to brisk mechanical displacements of the hair or glabrous skin of the contralateral fore- or hindlimb were included in this analysis. These were located 200-1200 $\mu \mathrm{m}$ deep to the cortical surface. We have previously demonstrated that NE exerts both a direct depressant action and a GABA-facilltating effect in these cells, mediated via a $\beta$-type adrenergic receptor ${ }^{38}$

Action potentials of single cerebrocortical neurons were amplified and displayed on an oscilloscope using conventional electrophysiological techniques. The neural signals were separated from background actıvity and converted to uniform voltage pulses by a window discriminator. These pulses were integrated over intervals of 1 or $2 \mathrm{~s}$ by an electronic ratemeter and the averaged firing rate of each cell displayed on a strip chart recorder to monitor responses to microiontophoretically applied test substances Once a suitable cell was identıfied (based on the above criteria) and a stable baseline of activity recorded, neuronal sensitivity to $\beta$-adrenergic stımulation was assessed by determining the mınımal iontophoretıc current of NE (or other agonist drug) required to produce a depression in spontaneous firıng (see below)

In judging neuronal sensitivity to agonists by iontophoretic methods it is essential to control for the varıability in drug release among different pipettes ${ }^{11}$.
To compensate for this variability, a strategy based on the high-low threshold method of iontophoretic testing devised by Schultz et al. ${ }^{34}$ was used to optimize drug ejection from any one micropipette and then the same micropipette was used to alternately record from cortical cells in tandemly prepared control and experimental anımals. Briefly, the threshold iontophoretic NE current required to depress spontaneous firıng of a neuron was determined by delivering regularly repeating 20-s pulses of drug (with $60 \mathrm{~s}$ between pulses to ensure recovery) at a sufficiently high level to elicit at least a $50 \%$ inhıbitory response. Drug pulses were then alternated between a similar fixed high effective current, designed to maintain a uniform tip concentration of drug in preparation for the subsequent low 'test' pulse, and a low NE 'test' current which was progressively reduced. With each double pulse cycle, the low NE current was further reduced until a level was reached which just produced an inhibitory response (defined as a $15-20 \%$ change from baseline); this current level defining the iontophoretic NE threshold. Changes in neuronal sensitivity to $\beta$-adrenergic stimulation after longterm opiate treatment were assessed by comparing the mean iontophoretic current thresholds of NE required to inhibit the firing of cerebrocortical cells recorded in chronic morphine-treated or morphınewithdrawn and chronic saline-treated anımals. Differences in mean iontophoretic current thresholds between control and experımental groups of anımals were evaluated statistically by means of two-talled Student's $t$-test and one-way analysis of variance.

\section{RESULTS}

\section{Assessment of morphine dependence}

The 14-day regimen of chronic morphine admınistration produced a high degree of physical dependence in the treated animals. Those chronically treated rats in which naloxone was admınistered displayed a prominent withdrawal syndrome which consisted of hyperactivity, spontaneous jumping, diarrhea accompanied by marked weight loss, teeth-chattering and/or wet-dog shakes. Rats that were withdrawn gradually from morphine displayed an abst1nence syndrome of somewhat dimınıshed intensity (1.e. no jumping), with weight loss at $32 \mathrm{~h}$ of withdrawal that typically exceeded $25 \%$ of total body weight 
In these latter animals, the earliest signs of withdrawal routinely appeared $10-12 \mathrm{~h}$ following the cessation of morphine treatment Similar changes in behavior and loss in body weight were not observed in either non-withdrawn experimental or saline-treated control animals.

\section{Changes in cortical $\beta$-adrenergic receptor binding}

High affinity binding of $\left[{ }^{3} \mathrm{H}\right] \mathrm{DHA}$ to the cortical neural membranes was rapid, saturable and reversible by propranolol $10^{-5} \mathrm{M}$ Computerized analysis of saturation bınding experiments indicated a single population of binding sites for $\left[{ }^{3} \mathrm{H}\right] \mathrm{DHA}$ with an apparent $K_{\mathrm{d}}$ of $0.87 \pm 0.09 \mathrm{nM}$ (controls, $n=5$ ) The fits obtained with a one ligand/one site model yielded Scatchard plots that were essentially linear, and these were significantly better than those obtained with a one ligand/two bindıng site model The max1mum number of specific binding sites $\left(B_{\max }\right)$ for $\left[{ }^{3} \mathrm{H}\right] \mathrm{DHA}$, as determined by the non-linear regression analysis program LIGAND, was $62.3 \pm 33$ $\mathrm{fmol} / \mathrm{mg}$ protein in the parietal cortex of control antmals. These $B_{\max }$ and $K_{\mathrm{d}}$ values for $\left[{ }^{3} \mathrm{H}\right] \mathrm{DHA}$ binding are in good agreement with those reported in rat cortex by other workers ${ }^{15,17}$

Chronic administration of morphine resulted in a significant increase in the binding of $\left[{ }^{3} \mathrm{H}\right] \mathrm{DHA}$ in the parietal cortex (Fig 1). The $B_{\max }$ for $\left[{ }^{3} \mathrm{H}\right] \mathrm{DHA}$ (86 1 $\pm 3.7 \mathrm{fmol} / \mathrm{mg}$ protein, $n=8$ ) was increased $38.2 \%$ $(P<0.002)$ in morphıne-dependent rats, when compared to salıne-treated controls (Table I, Fig. 1) This increase in density of cortical $\beta$-adrenergic binding sites occurred without a significant change in $K_{\mathrm{d}}$ for the radioligand (Table I) In addition, the Hill

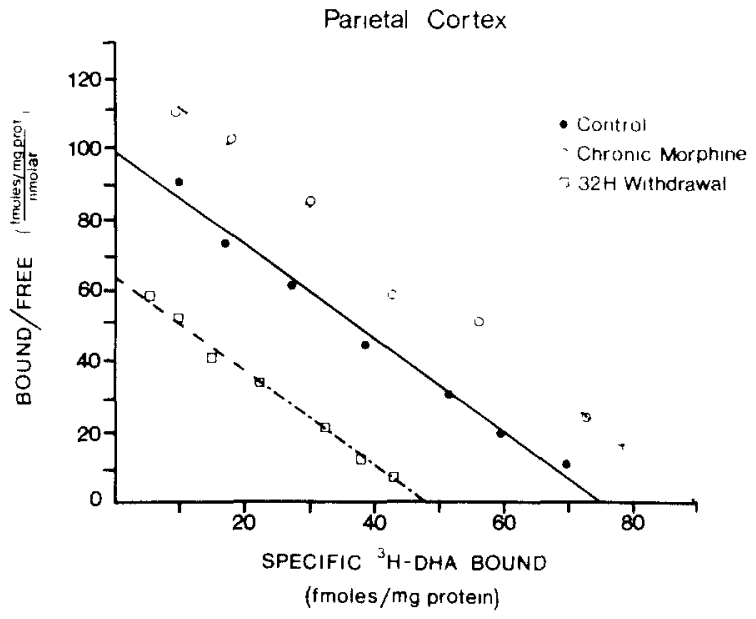

Fig 1 Scatchard plots showing the effects of chronic morphine treatment (open circles) and morphine withdrawal (open squares) on the specific binding of $\left[{ }^{3} \mathrm{H}\right] \mathrm{DHA}$ to neural membranes isolated from rat parietal cortex Data are from representative experiments Points plotted represent determinations, carned out in duplicate, of the binding of $\left[{ }^{3} \mathrm{H}\right] \mathrm{DHA}$ at concentrations of $01-256 \mathrm{nM}$ to membranes isolated from the cortices of 6 animals Binding affinities, indicated by the slopes of the regression lines drawn through the data points, were not changed after either treatment, whereas the maximum number of binding sites for $\left[{ }^{3} \mathrm{H}\right] \mathrm{DHA}$ (intercept with ordinate) was increased in the cortex after chronic morphine treatment and reduced following morphine withdrawal, relative to control Values for $B_{\max }$ and $K_{\mathrm{d}}$ were determined by non-linear regression using the computer program LIGAND

number for $\left[{ }^{3} \mathrm{H}\right] \mathrm{DHA}$ binding in the parietal cortex in morphine-dependent rats was unchanged compared to that for the saline-control group (Table I) These data strongly suggest that changes in the properties of the $\beta$-adrenergic receptors, themselves, are unlikely to account for the elevation in $\left[{ }^{3} \mathrm{H}\right] \mathrm{DHA}$ binding found in the cortex after chronic morphine treatment.

\section{TABLE I}

\section{Effects of chrontc morphine treatment and withdrawal on the specific binding of $\left.P^{3} H\right]$ dithydroalprenolol to rat cortical membranes}

Determinations of specific $\left[{ }^{3} \mathrm{H}\right]$ DHA binding to the cortical membranes were made $8 \mathrm{~h}$ (chronic morphine) and $32 \mathrm{~h}$ (withdrawn) after the last injection of a 14-day chronic morphine treatment schedule Cortices from 6 animals were pooled for each experıment Values represent the mean $\pm \mathrm{SEM}$ of the number of experiments shown

\begin{tabular}{|c|c|c|c|c|c|}
\hline \multirow[t]{2}{*}{ Treatment group } & \multirow{2}{*}{$\begin{array}{l}\text { Number of } \\
\text { experiments }\end{array}$} & \multicolumn{2}{|c|}{ Parameters of binding } & \multirow[b]{2}{*}{$n_{H}$} & \multirow[t]{2}{*}{$\%$ Change in $B_{\max }$} \\
\hline & & $\begin{array}{l}B_{\max } \\
\text { (fmolimg prot) }\end{array}$ & $\begin{array}{l}K_{d} \\
(n M)\end{array}$ & & \\
\hline Control & 5 & $623 \pm 3.3$ & $087 \pm 009$ & $103 \pm 003$ & \\
\hline Chronic morphine & 8 & $861 \pm 37^{*}$ & $114 \pm 015$ & $104 \pm 003$ & +382 \\
\hline 32-h withdrawn & 9 & $46.5 \pm 1.7^{* *}$ & $069 \pm 009$ & $106 \pm 001$ & -254 \\
\hline Acute morphine & 3 & $632 \pm 4.5$ & $088 \pm 020$ & $098 \pm 002$ & +14 \\
\hline
\end{tabular}

${ }^{*} P<0.002,{ }^{* *} P<0001$, compared to control values by Student's $t$-test (two-tailed) 
The increase in $\left[{ }^{3} \mathrm{H}\right] \mathrm{DHA}$ binding observed after chronic administration of morphine did not occur after acute treatment of rats with morphine $(30 \mathrm{mg} / \mathrm{kg}$, 1.p at 8-h intervals) for one day. In these acute experiments, specifıc binding of $\left[{ }^{3} \mathrm{H}\right] \mathrm{DHA}$ to the cortical membranes was determined at concentrations of radioligand from 1 to $25.6 \mathrm{nM}, 8 \mathrm{~h}$ after the last of 3 morphine injections. The $B_{\max }(63.2 \pm 45 \mathrm{fmol} / \mathrm{mg}$ protein, $n=3)$ and $K_{\mathrm{d}}(0.88 \pm 0.20 \mathrm{nM})$ for $\left[{ }^{3} \mathrm{H}\right] \mathrm{DHA}$ binding to membranes isolated from rats treated acutely with morphine did not differ significantly from corresponding values obtained for cortical $\left[{ }^{3} \mathrm{H}\right]$ DHA binding in the control group (Table I). Moreover, inclusion of up to $10^{-4} \mathrm{M}$ morphine in the incubation assay had no effect on the specific binding of $\left[{ }^{3} \mathrm{H}\right] \mathrm{DHA}$. Thus, the elevation in cortical $\beta$-adrenergic bindıng sites observed in morphine-dependent anımals appeared to emerge as a direct consequence of prolonged exposure to the opiate.

The effects of opiate withdrawal on cortical $\beta$-adrenergic receptors were assessed by examining the binding of $\left[{ }^{3} \mathrm{H}\right]$ DHA to cortical neural membranes isolated from chronic morphine-treated rats $32 \mathrm{~h}$ after administration of the last morphine injection. By this time the primary abstınence syndrome had become fully developed and in most anımals the 'dominant' withdrawal signs had already begun to subside. Withdrawal of the morphine-dependent subjects was accompanied by a decrease, relative to controls, in $\left[{ }^{3} \mathrm{H}\right]$ DHA binding in the parietal cortex (Fig. 1) The $B_{\max }$ for $\left[{ }^{3} \mathrm{H}\right] \mathrm{DHA}$ in cortex in the withdrawn animals, as determined by computer analysis, was 46.5 $\pm 17 \mathrm{fmol} / \mathrm{mg}$ protein $(n=9)$, which represented a decrease of $25.4 \%(P<0.001)$ and $46.0 \%(P<$ $0.001)$ in cortical $\beta$-receptor density, respectively, compared to saline-treated controls and morphinedependent animals (Table 1$)$. The $K_{\mathrm{d}}(0.69 \pm 0.09$ $\mathrm{nM})$ and Hill number for [ $\left.{ }^{3} \mathrm{H}\right] \mathrm{DHA}$ binding to cortical membranes isolated from morphine-withdrawn rats, however, were not significantly different from values obtained for control anımals (Table I).

Because the functional correlates of these changes in $\beta$-antagonıst bindıng were assessed physiologically in relation to the sensitivity of cerebrocortical neurons to NE agonists, it was important to also determine the effects of long-term morphine treatment on agonist affinity at cortical $\beta$-adrenergic receptors. These determinations were made by comparing the

\section{TABLE II}

Inhibution constants for norepinephrme and soproterenol at cortical $\left[^{3} \mathrm{H}\right]$ dihydroalprenolol binding sites in control, chronic morphine-treated and withdrawn rats

Experıments were carried out using pooled membranes isolated from the cortices of 6 rats Membrane suspensions were incubated in duplicate for $30 \mathrm{~min}$ with a fixed concentration of $\left[{ }^{3} \mathrm{H}\right] \mathrm{DHA}(2 \mathrm{nM})$ in the presence or absence of various concentrations of NE (100 nM-10 mM) or ISO (10 nM-0.1 mM) $\mathrm{IC}_{50}$ values were calculated by the iterative curve fitting program of Parker and Waud ${ }^{28} K_{1}$ values were calculated from the $\mathrm{IC}_{50}$ values by the method of Cheng and Prusoff ${ }^{6}$ There was no significant effect of chronic morphine treatment or morphine withdrawal on the inhibitory potencies of NE or ISO at $\left[{ }^{3} \mathrm{H}\right] \mathrm{DHA} \beta$-adrenergic receptor sites in cortex (two-talled Student's $t$-test) Each value is the mean \pm S E M. of 3 experiments

\begin{tabular}{lll}
\hline Drug & Treatment & $K_{\imath}(\mu M)$ \\
\hline NE & Control & $272 \pm 048$ \\
& Chronic morphine & $2.47 \pm 083$ \\
& Withdrawn & $136 \pm 047$ \\
ISO & Control & $027 \pm 015$ \\
& Chronic morphine & $031 \pm 009$ \\
& Withdrawn & $019 \pm 006$ \\
\hline
\end{tabular}

ability of the $\beta$-receptor agonists, ISO and NE, to compete with $\left[{ }^{3} \mathrm{H}\right] \mathrm{DHA}$ for $\beta$-adrenergic binding sites on cortical membranes prepared from control, chronic morphine-treated and morphine-withdrawn rats. The potencies of ISO and NE in competing for specific $\left[{ }^{3} \mathrm{H}\right]$ DHA binding sites were determined by incubating a fixed concentration of $\left[{ }^{3} \mathrm{H}\right] \mathrm{DHA}(2.6$ $\mathrm{nM})$ in the presence or absence of 8 concentrations of competing drug. The results of these experiments (Table II) indicated no significant change in the $K_{1}$ of ISO and NE against $\left[{ }^{3} \mathrm{H}\right] \mathrm{DHA}$ in the cortex after chronic morphine administration or morphine withdrawal. Moreover, there was no change in the slope of the competition curves after these experimental conditions (data not shown)

Electrophysiological assessments of neuronal sensittvity to iontophorettcally applied agonists

A total of 272 cerebrocortical neurons were studied for their responsiveness to $\beta$-adrenergic receptor stımulation. Forty-six of these neurons were recorded in morphine-dependent rats, 51 cells in morphine-withdrawn animals and 27 cells in animals treated acutely with morphine, with the remainder ( $n$ $=148$ ) comprising neurons recorded in matched sa- 
A

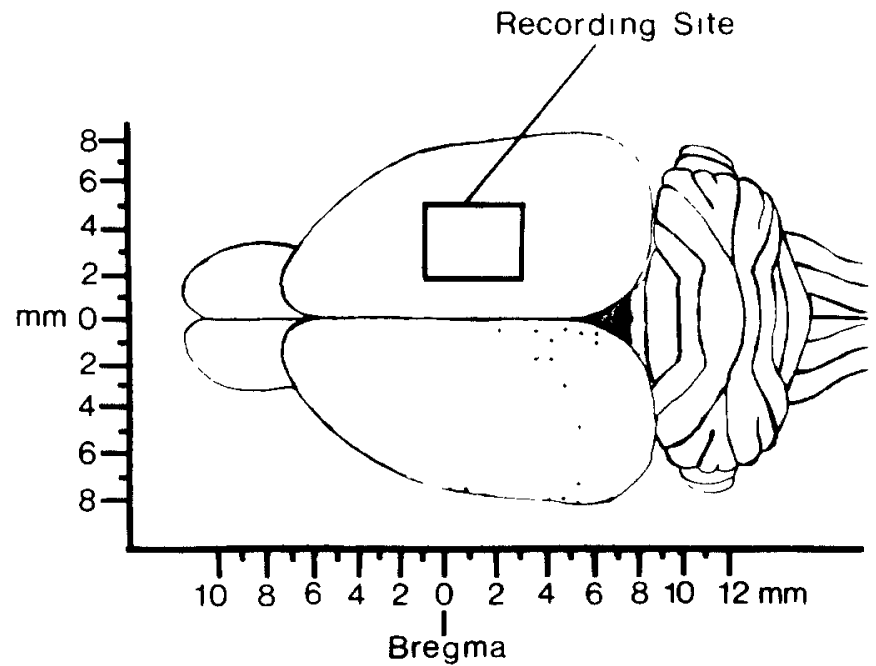

B
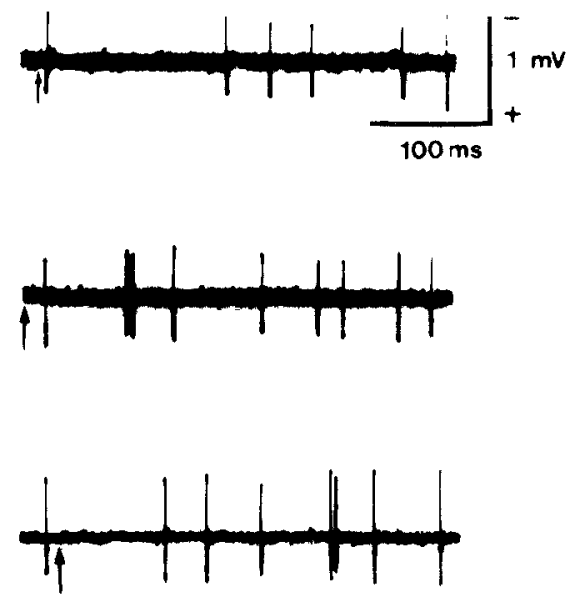

Fig 2 Recording site and responses of somatosensory cortical neurons to tactile stimulation of the contralateral footpad A dorsal view of rat brain showing the ared of the cortex (boxed-in area within right hemisphere) from which neuronal recordings were obtained Testing of chemosensitivity of cerebrocortical neurons to iontophoretically apphed drugs was carried out in both hemispheres The stıppled area over the left hemısphere indicates the region of cortıcal tissue (obtained bilaterally) used in the radıoligand binding experiments B oscilloscope records show the extracellularly recorded responses of cortical neurons to tactile stimulation of the contralateral forelımb (upper and lower traces) and hındlımb (middle trace) which were used to characterize cells prior to iontophoretic testing Stimulus onset is indicated by the drrow in edch record Note the difference in latency of the excitatory response between the neurons depicted in the upper and middle traces (see text for further detalls)

line-treated controls Fig. 2 shows oscilloscope recordings of neuronal responses to tactile stımulation of the fore- and hindlimb which were used as criteria for identıfying a relatively homogeneous population of cerebrocortical cells. The typical response elicited by the tactile stımulation consisted of a brief excitation (one to 3 spikes) at 6-31 ms latency, followed by a short period of inhibition (duration to 180 $\mathrm{ms})$, however, excitations alone (21\% of cases) or phases of pure inhibition (15\% of cases) were observed in some neurons (Fig. 2) Although cerveauisolé transection precluded the elicitation of this peripherally evoked activity in cortical units, the neurons $(n=24)$ recorded in the transected anımals ( $n=$ 8,4 controls and 4 morphıne-treated) displayed rates and patterns of spontaneous discharge remarkably sımilar to those of neurons recorded in halothane-anesthetızed rats. Moreover, no significant differences were noted in chemosensitivity to locally applied drugs between neurons in cerveau-1solé and anesthetized anımals which had been obtained from the same treatment group. Results obtained in anesthetized and cerveau-isolé preparations have, therefore, been grouped together according to the respective treat- ment group (1 e. salıne or chronic morphine) from which they came

The ratemeter records in Fig 3 illustrate the 'hıgh-low' threshold determination, using the same micropipette, of mınımal effective iontophoretıc currents of NE, (-)-1soproterenol ((-)-ISO) and GABA required to inhibit the spontaneous firnng of single cortical neurons in saline (record A) and chronic morphine-treated rats (record B). Fig. 4 shows the results of similar determinations of iontophoretic thresholds of these drugs required for the inhibition of neuronal firıng in a morphine-withdrawn anımal (record B), compared to a control rat (record A) In order to correlate these kinds of data with the results of radioligand binding, assessments of changes in neuronal chemosensitivity resulting from chronic morphine administration were carried out from 8 to $12 \mathrm{~h}$ following the last injection of the treatment regimen Similarly, determinations of chemosensitivity of cortical neurons in withdrawn rats were confined to a period extending from 32 to $36 \mathrm{~h}$ after the cessation of chronic morphine treatment

Iontophoresis of 20-s pulses of NE in the range of 10 to $65 \mathrm{nA}$ produced an inhibition in the sponta- 
A Control

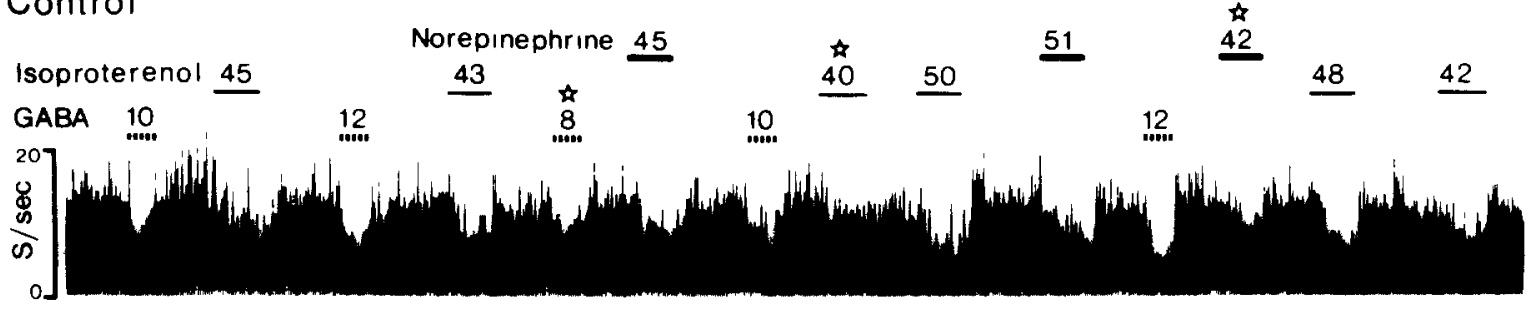

B Chronic Morphıne

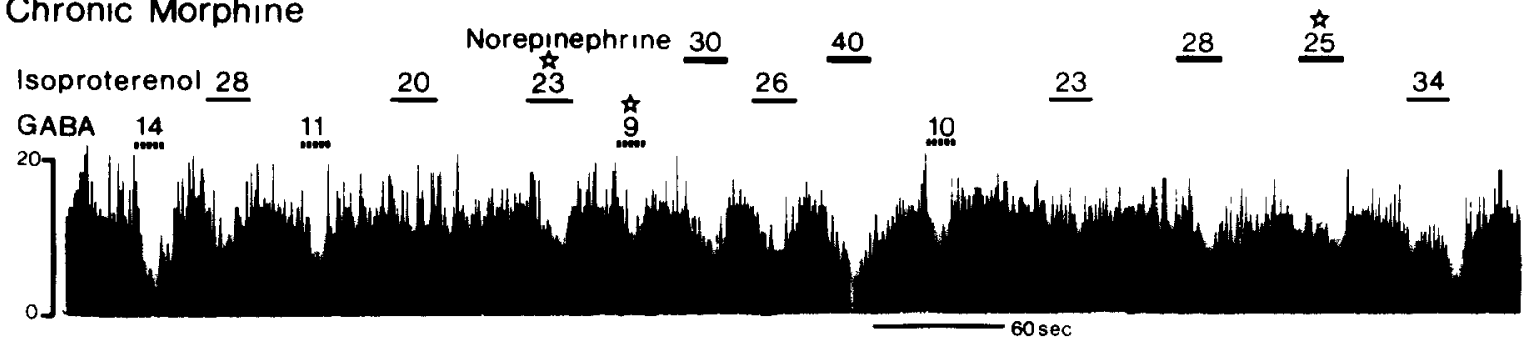

Fig. 3 Ratemeter records from a representatıve experıment demonstratıng use of the high-low threshold method for testıng sensitıvity to iontophoretically applied transmitter substances in cerebrocortical neurons from a control (A) and chronic morphine-treated an1mal (B). Assessments of chemosensitivity to iontophoretically applied NE (thick bars), (-)-ISO (thin bars) and GABA (dashed lınes) were carried out in tandem between neurons in control and morphine-treated rats, using the same micropipette Short bars above the ratemeter records indicate time of drug application and numbers above the bars refer to ejection current in nanoamperes Note that the cell tested in the chronic morphine-treated anımal (B) shows higher sensitivity to the direct inhibitory actions of NE (threshold, 25 $\mathrm{nA}$ ) and (-)-ISO (threshold, $23 \mathrm{nA}$ ) than the control cell (A) (thresholds of 42 and $40 \mathrm{nA}$, respectively), but that both neurons demonstrate similar chemosensitivity to GABA (thresholds of 8 and $9 \mathrm{nA}$ ) The minımal iontophoretic dose of drug required for inhıbition of spontaneous discharge of the neuron is indicated by a star above the corresponding ejection current. Assessments of chemosensitivity of neurons in chronic morphine-treated anımals were conducted between 8 and $12 \mathrm{~h}$ following cessation of chronic drug treatment

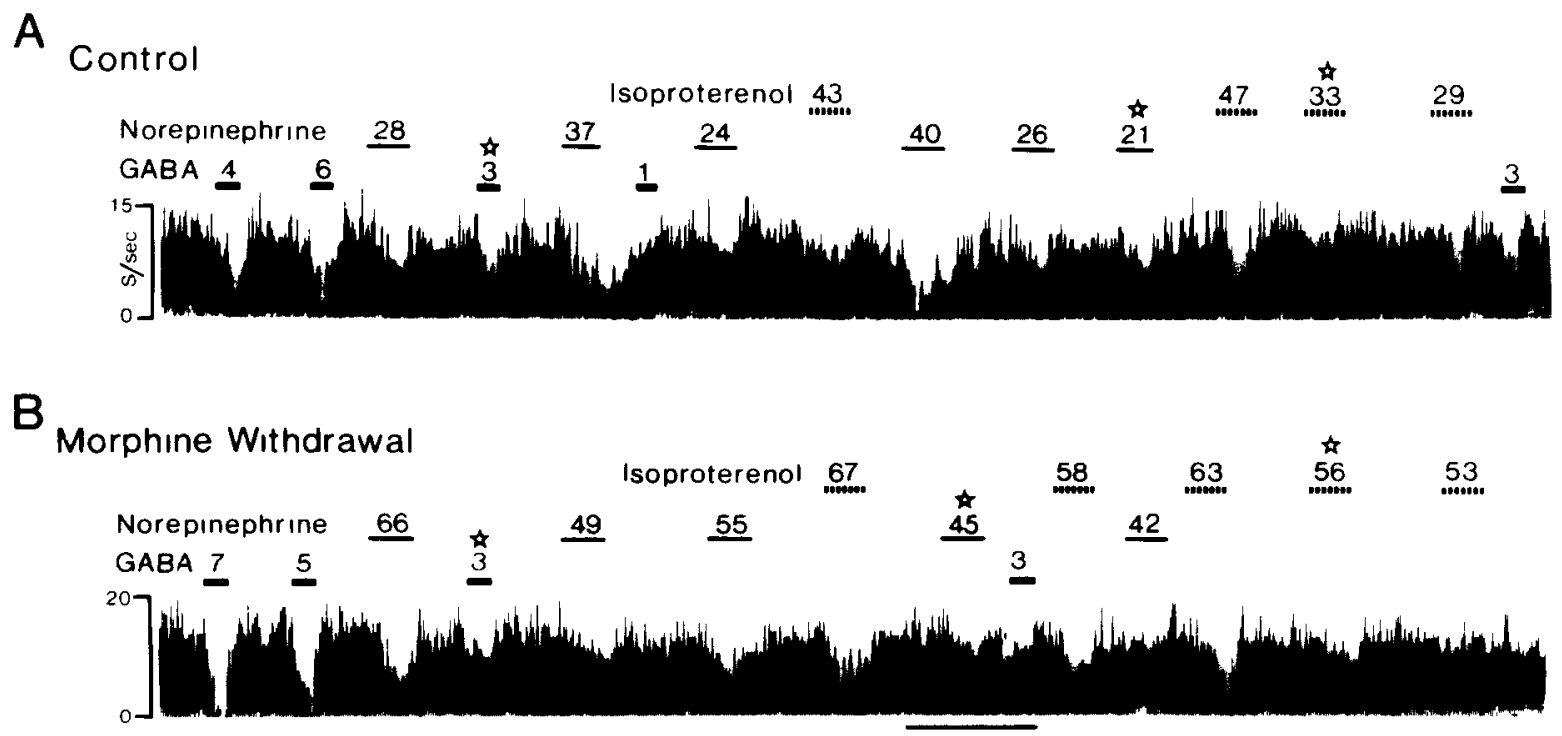

Fig 4 Contınuous ratemeter records from an experıment comparing sensitıvity to iontophoretically applied transmitter substances of cerebrocortical neurons in a control (A) and a morphine-withdrawn rat (B). The neuron recorded in the withdrawn animal displayed much lower sensitivity to iontophoretically applied NE (thin bar; threshold, $45 \mathrm{nA}$ ) and (-)-ISO (dashed line, threshold, $56 \mathrm{nA}$ ) than the control cell (thresholds of 21 and $33 \mathrm{nA}$ for NE and ISO, respectively) In comparison chemosensitivity to the inhibitory action of GABA (thick bar) was the same (threshold, $3 \mathrm{nA}$ ) for both neurons Chemosensitivity of neurons in control and withdrawn animals to each of the iontophoretically applied drugs was assessed using the same micropipette All tests in withdrawn anımals were conducted between 32 and $36 \mathrm{~h}$ following cessation of chronic morphine treatment Calibration line under record B indicates $60 \mathrm{~s}$ Other detalls as in legend to Fig 3 
TABLE III

Changes in cerebrocortical neuron sensitivity to tontophoretlcally applted transmitter substances following chrontc morphine treatment

Assessments of neuronal chemosensitıvity to iontophoretically applied substances were made 8-12 h following the last injection of a 14-day morphine treatment regimen Adrenergic agents were applied as 20-s pulses and GABA as a 10-s pulse

\begin{tabular}{|c|c|c|c|c|c|c|}
\hline \multirow[t]{2}{*}{ Agent } & \multirow[t]{2}{*}{ Cell pairs } & \multicolumn{3}{|c|}{ Mean threshold iontophorettc current ${ }^{2}$} & \multicolumn{2}{|c|}{ Spontaneous firing $(H z)^{n}$} \\
\hline & & Controls & Morphine- & ated & Controls & Morphine-treated \\
\hline$(-)-N E$ & 46 & $415 \pm 19$ & $273 \pm 14$ & $P<0001$ & $141 \pm 09$ & $139 \pm 11$ \\
\hline$(-)$-ISO & 37 & $318 \pm 15$ & $179 \pm 24$ & $P<0001$ & $129 \pm 15$ & $11+ \pm 16$ \\
\hline$(+)$-ISO & 17 & $461 \pm 21$ & $445 \pm 65$ & $\mathrm{~ns}$ & $163 \pm 24$ & $119 \pm 14$ \\
\hline GABA & 37 & $59 \pm 08$ & $69 \pm 10$ & $\mathrm{n} \mathrm{s}$ & $135 \pm 10$ & $143 \pm 13$ \\
\hline
\end{tabular}

${ }^{2}$ Data are expressed as the mean ( $\left.\pm S E M\right)$ threshold dose of drug (nA) required to produce an inhibition of spontaneous neuronal firing

b The spontaneous furing rates (expressed as mean \pm S E.M ) of cells recorded in control and chronıc morphine-treated rats were not significantly different $(P>0.25$, one-way analysis of variance)

neous firing of virtually all cortical neurons recorded in control animals. The spontaneous discharge of cortical neurons in both chronic morphine-treated and morphıne-withdrawn animals was, for the most part, also readily depressed by brief (20-s) 1ontophoretıc applications of NE (Figs. 3 and 4) In order to assess the $\beta$-adrenergic mediation of these depressant noradrenergic effects, inhibitory responses to NE were examined before and durng concurrent iontophoresis of the selective antagonists sotalol and phentolamine in 10 neurons from each treatment group. A specific blockade of NE-induced inhibitions in firıng was reliably produced by application of the $\beta$-antagonist sotalol ( 22 of 30 cells), but not the $\alpha$-antagonist phentolamine ( 3 of 30 cells) in cells in control, chronic morphine-treated and morphine-withdrawn anımals (data not shown).

Neurons recorded both in chronically morphinetreated animals and in morphine-withdrawn rats showed marked differences in sensitivity to 1ontophoretıcally applied NE, when compared to cells tested in saline-treated controls Tables III and IV give the mean iontophoretic currents required for inhibition of cortical neurons by various drugs in control, chronic morphine-treated and morphine-withdrawn rats. As shown in Table III, chronic administration of morphine resulted in a significant reduction (from $41.5 \pm 1.9$ to $273 \pm 1.4 \mathrm{nA} . P<0001$ ) in the mean threshold iontophoretic dose of NE required to inhibit cortical neuron firnng. These findıngs imply an increased sensitivity of neurons to NE in chronic morphıne-treated rats. In contrast, the mean threshold NE current required to depress neurons in morphine-withdrawn rats $(459 \pm 2.1 \mathrm{nA})$ was significantly $(P<0.001)$ greater than the mean threshold for control cells $(23.0 \pm 14 \mathrm{nA})$ (Table IV), indicating a reduced sensitivity to NE following withdrawal The tables also show that despite individual varia-

\section{TABLE IV}

Changes in sensitivity of cerebrocortical neurons to iontophoretically applied transmitter substances following morphine withdrawial

Assessments of chemosensitivity of individual neurons to iontophoretıc applications of adrenergic agonists (20-s pulses) and GABA (10-s pulses) were made $32-36 \mathrm{~h}$ following the cessation of chronic morphine treatment

\begin{tabular}{|c|c|c|c|c|c|c|}
\hline \multirow[t]{2}{*}{ Agent } & \multirow[t]{2}{*}{ Cell pairs } & \multicolumn{3}{|c|}{ Mean threshold iontophoretic current $t^{a}$} & \multicolumn{2}{|c|}{ Spontaneous firtng $(\mathrm{Hz})^{b}$} \\
\hline & & Controls & Morphine-v & thdrawn & Controls & Morphine-with- \\
\hline$(-)-N E$ & 51 & $230 \pm 14$ & $459 \pm 21$ & $P<0001$ & $171 \pm 09$ & $169 \pm 09$ \\
\hline (-)-ISO & 44 & $307 \pm 16$ & $492 \pm 24$ & $P<0001$ & $162 \pm 11$ & $148 \pm 13$ \\
\hline GABA & 51 & $53 \pm 06$ & $63 \pm 12$ & n s & $171 \pm 09$ & $160 \pm 09$ \\
\hline
\end{tabular}


A

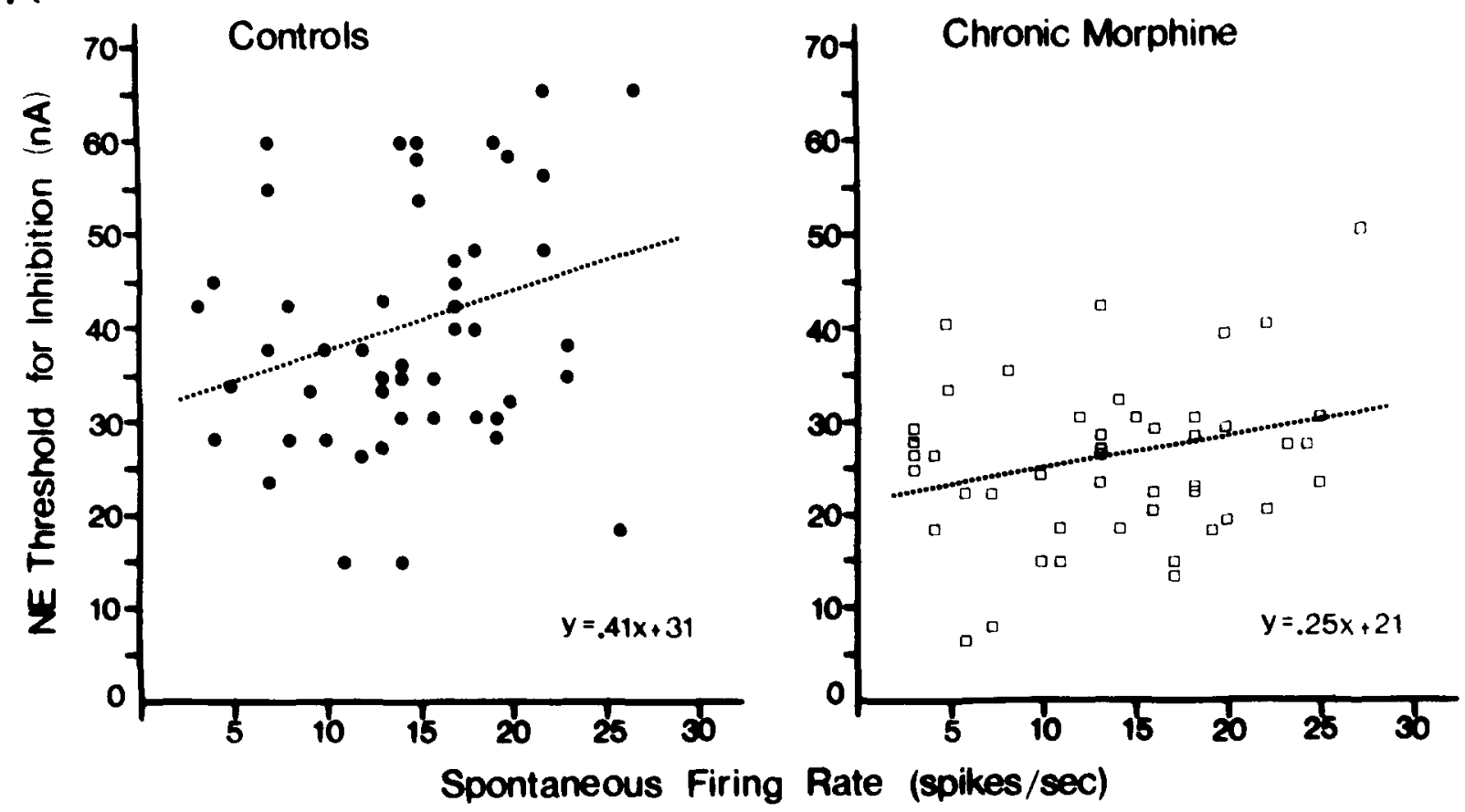

B
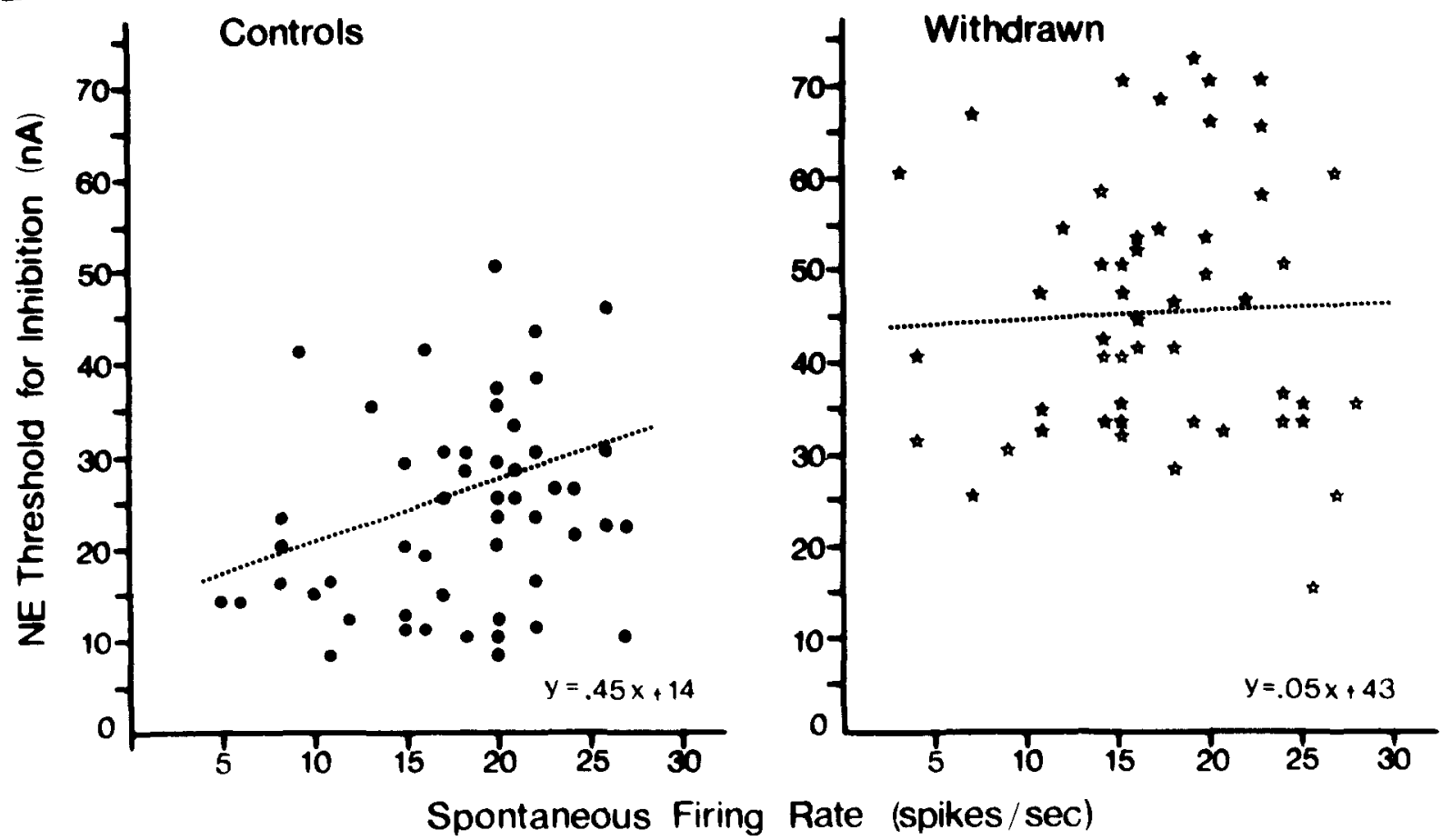

Fig. 5. Scatter plots show little evidence of correlation between sensitivity to iontophoretically applied NE and rate of spontaneous discharge of neurons in control (A and B, left panels), chronic morphine-treated (A, right panel) and morphine-withdrawn anımals (B, night panel) Each point plotted represents data from a different neuron Regression analysis of the data from each of the 4 groups yielded the sensitivity/rate lines shown with correlation coefficients of $r=019, P=0.19$ for chronic morphine controls; $r=0.20, P=$ 018 for chronic morphine-treated cells; $r=0.25, P=008$ for withdrawn controls; and $r=0.04, P=078$ for withdrawn neurons A the slopes of the sensitivity/rate lines for control and experimental groups were compared using the test of Zerbe et al ${ }^{39}$ to control for a possible biasing of the results due to the presence of rate as a co-variant. This analysis showed cortical neurons from chronic morphinetreated rats to be significantly more sensitive to NE than control cells $(P<0.01)$ B neurons recorded in morphine-withdrawn anımals were found in turn to be significantly less sensitive to NE than cells in matched controls $(P<0005)$ The controls for the chronic morphine-treated and -withdrawn groups consisted of entirely separate populations of cerebrocortical neurons 
tions, the mean rates of spontaneous firing of cortical units recorded in chronic morphine-treated and in morphıne-withdrawn anımals did not differ signitıcantly from that of matched salıne controls (Tables III and IV) No correlation was found between the initial rate of spontaneous discharge of a neuron and the minimal effective iontophoretic dose of NE required to inhibit firing in either control $(r=019, P=$ 019 for chronic group; $r=025, P=008$ for withdrawn group), chronic morphine-treated $(r=0,20, P$ $=018)$ or withdrawn animals $(r=004, P=078)$ (Fig. 5). Moreover, when the data were re-examıned controlling for initial firing rate of the cell as a possible covariant, neurons in chronic morphine-treated and withdrawn rats were still found to be significantly more $(P<001)$ and less sensitive $(P<0.005)$ to NE, respectively, than control cells (Fig. 5)

It should be noted that the assessments of changes in cortical neuron sensitivity to NE in morphine-dependent and morphıne-withdrawn rats were conducted several months apart, and that different groups of salıne-treated anımals served as matched controls in each series of experiments Cortical neurons recorded in the two groups of control animals displayed a considerable difference in sensitivity to iontophoretically applied NE (but not ISO, cf Tables III and IV) This was most likely related to inherent differences in catecholamine release between the micropipettes used in each of the studies. rather than an indication of considerable variability in the normal range of NE chemosensitivity of the cerebrocortical neurons In this regard, no significant difference in mean iontophoretic inhibitory thresholds of NE was found in experiments $(n=3)$ in which the same micropipette was used to assess chemosensitivity in matched-pairs $(n=12)$ of cerebrocortical neurons recorded in tandemly prepared salıne-treated control rats

Changes in cellular excitability have been reported during morphine dependence and withdrawal ${ }^{12,33}$ which, by themselves, might affect the postsynaptic sensitivity of neurons to exogenously applied catecholamınes. Therefore, to control for the specificity of the changes in NE thresholds found among cortical neurons in chronic morphine-treated and -withdrawn rats, iontophoretic current thresholds of GABA required for unhibition of firıng were also determined for most cells (Figs. 3 and 4) No sıgnificant differ- ences (all $P$ values $>01$ ) in the mean current the $h$ holds for inhibition by GABA were tound betucen neurons in chronically morphine-treated and morphine-withdrawn animals, when compared to control cells (Tables III and IV)

The specificity of the increase in noradrenergic sensitivity found in neurons in morphine-dependent anımals was assessed further by examınıng the effects of prolonged morphine treatment on cortical neuron responsiveness to Iontophoresis of $(+)$-isoproterenol $((+)-$ ISO), an adrenergic agent which has been shown in other test systems to be largely inactive in stımulatıng $\beta$-receptors ${ }^{\text {in } 211}$ The effects of iontophoresis of $(+)$-ISO on cortical unit activity were examined on 25 parrs of neurons recorded in 6 control and 6 chronic morphine-treated rats. Pulsatile applicdtions of (+)-ISO of $20 \mathrm{~s}$ duration depressed the ongoIng activity of 38 of these neurons ( 20 control and 18 treated cells): however. these effects required a much higher range of iontophoretic doses $(30-75$ $\mathrm{nA}, 472 \pm 6 \mathrm{nA}$, mean $\pm \mathrm{S} E \mathrm{M}$ ) than was needed to produce inhibitory responses with the tull $\beta$-receptor agonist, $(-)$-ISO (see below). Changes in sensitivity of cortical neurons to (+)-ISO following chronic morphine administration were assessed by comparıng the minımal effective iontophoretic currents of drug required to inhibit the firing of cells recorded in control and morphine-dependent rats In exper1ments performed on 17 tandemly studied cell parrs. no significant difference $(P>025)$ was found in sensitivity to $(+)$-ISO between neurons in control and chronic morphine-treated animals (Table III) These findings. when considered in conjunction with the results of experiments with GABA, argue aganst the possibility that a non-specific change in cellular excitability accounted for the alterations in noradrenergic sensitıvity found in cortical neurons in morphine-dependent and morphine-withdrawn anımals

In order to differentiate the involvement of preversus postsynaptic components in the changes in noradrenergic sensitivity found following chronic morphine treatment and withdrawal, analogous experiments were conducted using (-)-ISO which is not a substrate for the high affinity NE reuptake system ${ }^{5}$. The sensitivity to (-)-ISO of neurons in both morphine-dependent ( 37 cells in 12 rats) and morphinewithdrawn animals ( 44 cells in 12 rats) differed signifIcantly $(P<0001)$ from that of control cells (Figs 3 
Control

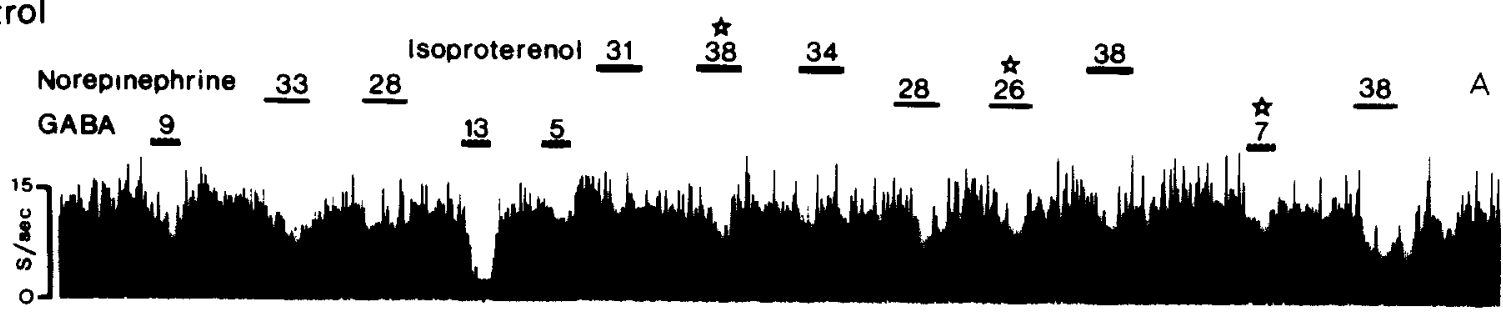

Acute Morphine

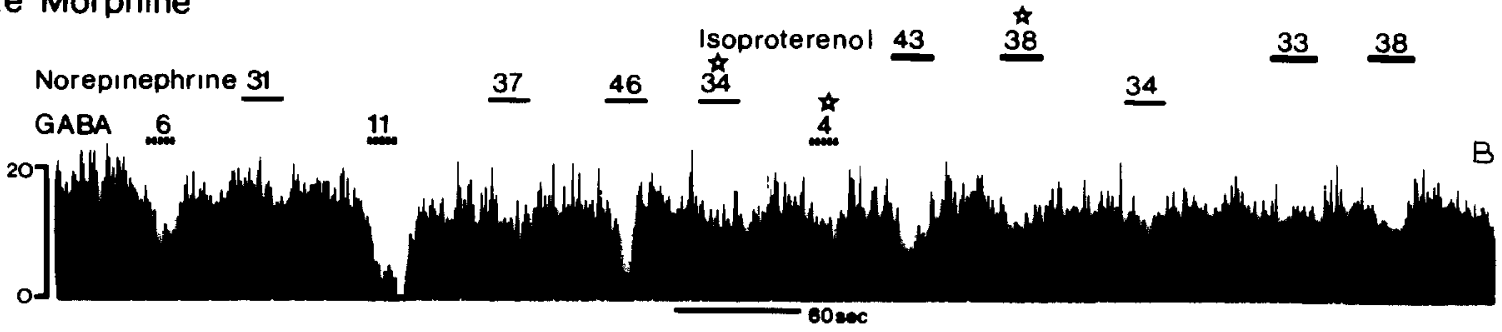

\section{Morphine lontophoresis}

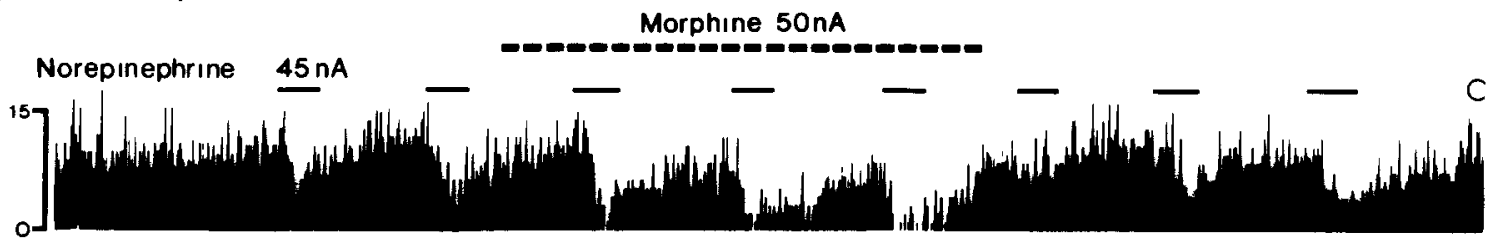

Fig. 6. Effects of acute and local administration of morphine on the sensitivity of cerebrocortical neurons to iontophoretically applied transmitter substances Acute treatment of rats with morphıne, $30 \mathrm{mg} / \mathrm{kg}$ t.1.d., for one day (B) did not significantly alter cortıcal neuron responses to Iontophoretıcally appied NE (thın bar), (-)-ISO (thick bar) or GABA (dashed line), relative to the actions produced by these substances in control cells (A). In these experiments, the same micropipette was used to assess chemosensitivity of cortical neurons recorded in control (A) and acute morphine-treated rats. Other details as in legend to Fig $3 \mathrm{C}$ contınuous ratemeter record showing inhibitory responses of a cortical neuron in a naive rat to iontophoretically applied NE ( $45 \mathrm{nA}$, thin line) before, during and after concurrent iontophoresis of morphine ( $50 \mathrm{nA}$, dashed line) onto the cell During morphine iontophoresis spontaneous discharge of the cell was considerably depressed, whereas the inhibitory response to NE showed little appreciable change The apparent increase in NE-induced inhibition observed 3 min after onset of morphine iontophoresis can be attributed to a simple summation of depressant effects produced by both agents.

and 4). Whereas chronic morphine treatment resulted in a marked reduction in the iontophoretic current threshold for unhibition by (-)-ISO (17.9 \pm 2.4 $\mathrm{nA}$, mean \pm S.E.M.; 8 to $28 \mathrm{nA}$, range), significantly higher iontophoretic currents of the agonist were required to inhibit the firing of cortical neurons in withdrawn anmals $(49.2 \pm 2.4 \mathrm{nA}$, mean \pm S.E.M.; 23 to $65 \mathrm{nA}$, range), compared to control cells (14 to 50 $\mathrm{nA}$, range) (Tables III and IV). In all cases, chemosensitivity to GABA was also determined for each neuron, providing a control for assessing receptor specificity. No significant differences (all $P$ values $>$ 0.1 ) were found between the mean GABA thresholds required to inhibit firing of neurons in chronic morphine-treated and -withdrawn animals, when compared to control cells (Tables III and IV).

In a final set of experiments, an identical type of analysis was carried out to examine the possibility that the presence of residual levels of morphine in brain might contribute to the increase in noradrenergic sensittvity found in cortical neurons after chronic morphıne admınistration. For these acute studies, determinations of the sensitivity of neurons to iontophoretically applied transmitters were carried out in tandemly prepared control and morphine-treated rats 8 $\mathrm{h}$ following administration of the last of 3 morphine (30 $\mathrm{mg} / \mathrm{kg}$, i.p at 8 -h intervals) or saline injections. The upper and middle records in Fig. 6 show the results of a typical experıment. A comparison of these ratemeter records reveals no obvious differences in 
I ABLE $V^{\prime}$

Changes in sensitwitt of cerebrocortical neurons to iontophoreticallv appled transmitter substances following one-day morphine' treatment

Rats were given $31 \mathrm{p}$ injectıons of morphine $(30 \mathrm{mg} / \mathrm{kg})$ or salıne at 8 -h intervals for one day Eight hours atter admınıstering the last injection, assessments were made of the sensitivity of neurons in these animals to iontophoretically applied adrenergic dgonists and GABA

\begin{tabular}{|c|c|c|c|c|c|}
\hline \multirow[t]{2}{*}{ Agent } & \multirow[t]{2}{*}{ Cell pairs } & \multicolumn{2}{|c|}{ Mean threshold tontophorettc current } & \multicolumn{2}{|c|}{ Spontaneous firing $(\mathrm{Hz})^{h}$} \\
\hline & & Controls & Morphine-treated & Controls & Morphine-treuted \\
\hline$(-)-N E$ & 27 & $27+ \pm 24$ & $331 \pm 27$ & $122 \pm 13$ & $124 \pm 17$ \\
\hline$(-)-\mathrm{ISO}$ & 22 & $351 \pm 22$ & $398 \pm 33$ & $109 \pm 17$ & $128 \pm 15$ \\
\hline GABA & 25 & $61 \pm 09$ & $68 \pm 12$ & $12+ \pm 13$ & $12+ \pm 17$ \\
\hline
\end{tabular}

a Data are expressed as the mean $( \pm S E M)$ threshold dose of drug (nA) required to produce an inhibition of spontaneous neuronal firing

$\mathrm{h}$ The spontaneous firing rates (expressed as mean $\pm \mathrm{S} E \mathrm{M}$ ) of cells recorded in salıne-treated control and morphine-treated rats were not significantly different $(P>0.5$. one-way analysis of variance)

responsiveness of the neuron in the control (Fig. 6A) and acute morphine-treated rat (Fig 6B) to noradrenergic or GABAergic stımulation Overall, no significant differences (all $P$ values $>0.25$ ) were found in the mean 1ontophoretic inhibitory thresholds for NE, (-)-ISO or GABA between cerebrocortical neurons recorded in control and in acute morphinetreated anımals (Table V). In addition, local application of morphine directly onto cerebrocortical neurons had little appreciable effect on postsynaptic depressions in cell firing produced by NE iontophoresis (Fig. 6C) in either control (8 neurons in 3 rats) or acute morphine-treated rats ( 7 cells in 4 rats)

\section{DISCUSSION}

The results of this study confirm and extend earler findings ${ }^{9.17}$ that chronic, but not acute, administration of morphine results in an increased density of $\beta$ adrenergic receptors in rat cerebral cortex. Using an incremental schedule of morphine injections to make anımals tolerant and dependent, we observed a $382 \%$ increase, relative to control, in the $B_{\max }$ for $\left[{ }^{3} \mathrm{H}\right] \mathrm{DHA}$ in the parietal cortex in chronic morphinetreated rats. This increase in $\beta$-adrenergic receptor density was measured $8 \mathrm{~h}$ following cessation of opiate treatment when animals were judged to still be in a dependent state, owing to the absence of demonstrable withdrawal behavior or signs In comparison, when binding of $\left[{ }^{3} \mathrm{H}\right] \mathrm{DHA}$ was carried out $32 \mathrm{~h}$ after administration of the last morphine injection, a significant decrease $(25.4 \%)$ in $\beta$-adrenergic receptors was found in the parietal cortex in morphine-withdrawn rats, compared to saline-treated controls. These alterations in the density of $\left[{ }^{3} \mathrm{H}\right] \mathrm{DHA}$-labelled $\beta$-adrenergic receptors occurred without significant change in either the $K_{\mathrm{d}}$ or Hill number for the antagonist, suggesting that the character (intrinsic properties) of the $\beta$-adrenergic receptors found in the cortex in morphine-dependent and morphine-withdrawn rats may be identical to the natıve binding sites for $\left[{ }^{3} \mathrm{H}\right] \mathrm{DHA}$ Consistent with this interpretation is the finding that the potencies of the $\beta$-adrenergic agonısts, NE and ISO, in competıng for specific $\left[{ }^{3} \mathrm{H}\right]$ DHA binding sites in the parietal cortex were also unchanged following chronic morphine treatment or withdrawal.

The time course of the elevation in $\beta$-adrenergic receptor density found in the parietal cortex after chronic morphine treatment suggests that the up-regulation of these receptors may be related in some way to the formation of the dependent state. Supporting this possibility are the findings of Hamburg and Tallman ${ }^{9}$, who reported a progressive increase in $\left[{ }^{3} \mathrm{H}\right] \mathrm{DHA}$ binding in the cortex with increased time of exposure to morphine in rats implanted with morphine pellets for up to 3 days It was further shown that the increase in cortical $\beta$-adrenergic receptor density observed after chronic morphine treatment could be completely reversed by abruptly withdrawing the dependent anımals with naloxone $1 \mathrm{~h}$ prior to sacrifice The addition of naloxone in vitro did not affect the binding of $\left[{ }^{3} \mathrm{H}\right] \mathrm{DHA}$ to cortical membranes ssolated from either control or chronic morphine- 
treated animals, leading these workers to suggest that the effects produced by administration of the antagonist in vivo could most likely be attributed to a precipitation of withdrawal (in the morphine-dependent subjects) and the increase in central noradrenergic activity which accompanies it ${ }^{1,30,32}$. Conceivably, such a withdrawal-induced activation of central noradrenergic pathways, leading to an increased postsynaptic availability of NE, could account in similar fashion for the down-regulation in $\beta$-adrenergic receptors observed here in the parietal cortex in the withdrawn animals.

A primary objective of the present study was to determine whether the changes in $\beta$-adrenergic receptor density that result after chronic morphine treatment or withdrawal are reflected in corresponding alterations in the sensitivity of individual cortical LC target cells to noradrenergic stimulation. Using a high-low threshold method of iontophoretic testing to assess the responsivity of neurons to postsynaptically applied transmitters, we were able to demonstrate that the increase in $\beta$-adrenergic receptor density that occurred in the parietal cortex after chronic morphine treatment was temporally correlated with an increased neuronal sensitivity to NE within the same brain area. Conversely, neurons that were tested in animals that had undergone withdrawal from morphine were found to exhibit a subsensitivity to noradrenergic stimulation, compared to cells in controls, at a time when measurements of $\left[{ }^{3} \mathrm{H}\right] \mathrm{DHA}$ binding revealed that the density of $\beta$-adrenergic receptors in that region of the cortex was substantially reduced. All of the cells in which noradrenergic sensitıvity was assessed were characterized initıally as mechanoreceptive units and responded to tactile input originatıng from either the contralateral forelimb or hindlimb. Previous studies in this ${ }^{38}$ and other laboratories ${ }^{2,3,27}$ have indicated that the inhibitory effects of NE on spike discharge in these neurons are mediated directly via the activation of postsynaptic $\beta$ adrenergic receptors. It seems likely, therefore, that the changes in $\beta$-adrenergic receptor density that were revealed through alterations in $\left[{ }^{3} \mathrm{H}\right]$ antagonıst binding to some extent involve these populations of postsynaptic neuronal receptors and may thus be of physiological relevance.

Several lines of evidence suggest that the changes in noradrenergic responsiveness observed in neurons
In chronic morphine-treated and -withdrawn rats reflect the development of supersensitivity and subsensitivity in postsynaptic $\beta$-adrenergic receptors, respectively. First, the changes in electrophysiological responsiveness to $\mathrm{NE}$ that accompanied morphine dependence and withdrawal occurred without alterations in the chemosensitivity of cortical neurons to the inhibitory effects of GABA or of (+)-ISO, an adrenergic agonist which is largely inactive in stımulating $\beta$-adrenergic receptors ${ }^{16,20}$. Second, these changes in noradrenergic responses of neurons in chronic morphine-treated and -withdrawn anımals were reproduced in tests with (-)-ISO, a $\beta$-selective agonist which is not a substrate for the NE reuptake system ${ }^{5}$. Alterations in the neuronal reuptake of $\mathrm{NE}^{7}$ or a non-specific change in cellular excitability ${ }^{12,33}$ are thus unlikely to account for the changes in noradrenergic sensitivity found in cortical neurons following long-term morphine treatment or withdrawal. Finally, local application of morphine directly onto cortical cells did not appreciably alter NE-induced inhibitions in firing elicited in neurons of either control or experimental animals. This suggests that alterations in NE activity at neuronal receptors resultıng from a residual presence of morphine in the brain are also unlikely to account for the electrophysiological changes reported here. Taken together, these data make it likely that the changes in neuronal responsiveness to $\beta$-adrenergic stimulation that occur after chronic morphine treatment and durıng withdrawal reflect adaptations or adjustments involving postsynaptic components of the adrenergic system residing in the neurons.

The finding that the changes in cortical $\beta$-adrenergic receptor density observed during morphine dependence and withdrawal were accompanied by corresponding alterations in electrophysiological responsiveness to NE does not, by itself, establish a causal relationship between the changes in receptor number and the alterations in noradrenergic response of the effector cells. Clearly, these changes in the responsiveness of neurons to NE need not be related solely to adjustments in the number of $\beta$-adrenergic receptors residing on the postsynaptic membrane, but could also reflect postreceptor events which ultimately lead to the electrophysiological response. Some studies suggest that the inhibitory effects of NE on cortical neurons may be mediated via 
the coupling of $\beta$-receptors to adenylate cyclase ${ }^{35}$, and an increase in ISO-stimulated cyclic AMP accumulation has been reported to accompany elevations in $\beta$-adrenergic receptor density in rat cortex following chronic morphine treatment ${ }^{17}$. It should be noted that this enhanced responsiveness of the cyclic AMP system to ISO exceeded the increase observed in receptor density, suggestıng the likelihood of compensatory changes beyond a simple increase in the number of $\beta$-adrenergic binding sites. Interestıngly, $\mathrm{Ku}$ riyama et al ${ }^{14}$ have recently reported that the coupling between $\beta$-adrenergic receptors and adenylate cyclase in rat cerebral cortex may be facilitated durIng acute withdrawal. The functional tests used here to assess changes in noradrenergic responsiveness in cortical neurons provide little insight regarding the locus of change in the postsynaptic adrenergic system which underlies the electrophysiological changes Nevertheless, the demonstration here of a strong concordance between the changes in radioligand binding and electrophysiological responsiveness to NE observed among chronic morphine-treated and -withdrawn animals can be interpreted to support some form of linkage between the alterations in cortical $\beta$-adrenergic receptor density and in noradrenergic responsitivity that emerge durıng morphıne dependence and withdrawal.

It is presently unclear to what extent alterations in $\beta$-adrenergic receptor density in the brain might contribute either in the formation or expression of dependence on morphine In some studies where increases in cortical $\beta$-adrenergic receptor density have been reported in rats treated chronically with morphine, the up-regulation in receptors was noted only after the precipitation of withdrawal in the dependent anımals ${ }^{13,15}$ In contrast, the results of the present study demonstrate clearly that $\beta$-adrenergic receptors are increased in the cortex pror to the onset of withdrawal in morphine-dependent anımals and down-regulated during later stages of abstinence at a time when the withdrawal syndrome has become fully manifested This discrepancy in results between these studies may be related, in part, to differences in

\section{REFERENCES}

1 Aghajanian, G K , Tolerance of locus coeruleus neurones to morphine and suppression of withdrawal response by clonidine, Nature (London), 276 (1978) 186-188 the timing of receptor binding following spontaneous and naloxone-precipitated withdrawal of the chronic morphine-treated animals One possibility is that while the elevation observed in cortical $\beta$-adrenergic receptors may be related to events occurring during dependence, ultimately this up-regulation in postsynaptic receptors could contribute in the formation and/or occurrence of the withdrawal syndrome. The emergence of supersensitivity in central $\beta$-adrenergic receptors is unlikely, however, to be primarily responsible for the sympathetic hyperactivity which characterızes the primary abstinence syndrome, since the administration of $\beta$-adrenergic receptor blockers, such as propranolol, does not appreciably reduce withdrawal signs in human addicts ${ }^{31}$ A second possibility is that the alterations in $\beta$-adrenergic receptor density that result after long-term morphine treatment might reflect compensatory adaptations of these postsynaptic systems to changes in turnover rate of NE in the brain (and hence, transmitter avallability) which are known to accompany opiate withdrawal ${ }^{30.32}$ In this regard, the down-regulation in cortical $\beta$-adrenergic receptors that was found in the dependent anımals during later stages of abst1nence could result from the central noradrenergic hyperactivity which occurs during the acute withdrawal phase in both rats and primates ${ }^{31} 32$ If the receptor down-regulation found in the cortex were to prove indicatıve of a subsensitivity in postsynaptıc $\beta$-adrenergic receptors in LC terminal fields throughout the neuraxis, such a change in noradrenergic responsiveness could account, in part, for the signs of uoradrenergic hypoactivity which comprise the 'secondary' or protracted abstınence syndrome observed clinically ${ }^{19}$ Studies are currently underway in this laboratory to investigate this possibility

\section{ACKNOWLEDGEMENTS}

This work was supported by USPHS Grants DA03365 and DA-00254, and an award from The Chicago Community Trust/Searle Scholars Program to H.M.

2 Armstrong-James, $M$ and Fox, $K$. Effects of 1onophoresed noradrenaline on the spontaneous activity of neurons in rat primary somatosensory cortex, $J$ Physiol (London), 335 (1983) $427-447$

3 Bevan. P, Bradshaw, C and Szabad, E . Pharmacology of 
adrenergic neuronal responses in the cerebral cortex: ev1dence for excitatory $\alpha$ - and $\beta$-inhibitory receptors, $B r . J$ Pharmacol, 59 (1977) 635-641.

4 Blasig, J , Herz, A. and Gramsch, C , Effects of depletion of brain catecholamines during the development of morphine dependence on precipitated withdrawal in rats, $\mathrm{Nau}$ nyn Schmtedeberg's Arch Pharmacol, 286 (1975) 325-336

5 Burgen, A S V and Iversen, L L, The inhibition of noradrenaline uptake by sympathomımetic amınes in the rat isolated heart, $\mathrm{Br} J$ Pharmacol, 25 (1965) 34-49

6 Cheng. $Y$ and Prusoff, $W$, Relationship between the inhibition constant $\left(K_{1}\right)$ and the concentration of inhibitor which causes 50 percent inhibition $\left(\mathrm{IC}_{50}\right)$ of an enzymatic reaction, Blochem Pharmacol, 22 (1973) 3099-3108

7 Clouet, D H and Williams, N , The effect of narcotic analgesic drugs on the uptake and release of neurotransmitters in isolated synaptosomes, $J$ Pharmacol. Exp Ther, 188 (1973) 419-428

8 Gold, M S , Redmond, D E and Kleber, H D., Noradrenergic hyperactivity in opiate withdrawal supported by clonıdine reversal of opiate withdrawal, Am J Psychiatry, 136 (1979) $100-102$

9 Hamburg, $M$ and Tallman, J F, Chronic morphine admınistration increases the apparent number of $\alpha_{2}$-adrenergic receptors in rat brain, Nature (London), 291 (1981) $493-495$

10 Herz, A, Blasig, J and Papeschi, R, Role of catecholaminergic mechanisms in the expression of the morphine abstınence syndrome in rats, Psychopharmacologia, 39 (1974) 121-143

11 Hoffer, B J , Neff, N H and Siggins, G R, Microiontophoretic release of norepınephrine from micropipettes, Neuropharmacology, 10 (1971) 175-180

12 Johnson, S M and North, R A , Membrane potential changes in neurons undergoing withdrawal from opiates, Brain Research, 190 (1980) 559-563

13 Kuriyama, K , Muramatsu, M , Ohkuma, S , Tamura, J -I and Ping, $Z$ P , Differential effects of morphine withdrawal on cerebral $\beta_{1}$ - and $\beta_{2}$-adrenergic receptors. $J$ Neuroscl Res , 6 (1981) 749-755

14 Kuriyama, K, Muramatsu, M, Ohkuma, S and Tamura, $\mathrm{J}$-I , Alteration in the effect of GTP on cerebral $\beta$-adrenergic receptor binding during morphine withdrawal, Eur $J$ Pharmacol, 91 (1983) 411-419

15 Kuriyama, K, Muramatsu, $M$ and Ueno, $E$, Alteration in $\beta$-adrenergic receptor binding in brain, lung and heart during morphıne and alcohol dependence and withdrawal, Neuropharmacology, 20 (1981) 659-666

16 Langer, S Z, Presynaptic regulation of the release of catecholamınes, Pharmacol Rev, 32 (1982) 337-362

17 Llorens, C, Martres. M P , Baudry, M and Schwartz, $\mathrm{J} C$. Hypersensitivity to noradrenaline in cortex after chronic morphine relevance to tolerance and dependence, Nature (London), 274 (1978) 603-605

18 Lowry, O H , Rosebrough. N J., Farr, A L and Randall, R J , Protein measurement with the Folin phenol reagent, J Biol Chem . 193 (1951) 265-275

19 Martın. W E and Jasınskı, D R , Physıological parameters of morphine dependence in man-tolerance, early abstınence, protracted abstınence, $J$ Psychiat Res, 7 (1969) 9-17

20 Mattıo, T G and Kırby, M L . Effects of chronic morphine admınıstration on catecholamınes and $\beta$-adrenergıc recep- tors of the superior cervical ganglion and iris of the rat, Life Scl., 30 (1982) 1435-1442.

21 McPherson, G.A., A practical computer-based approach to the analysis of radioligand binding experıments, Comput. Programs Bıomed., 17 (1983) 107-114

22 Minneman, K P., Dibner, M.D., Wolfe, B.B and Molinoff, $\mathrm{P}, \beta_{1}$ - and $\beta_{2}$-adrenergic receptors in rat cerebral cortex are independently regulated, Sctence, 204 (1979) $866-868$

23 Minneman, K.P , Pittman, R N and Molinoff, P B , $\beta$-adrenergic receptor subtypes. properties, distribution, and regulation, Annu Rev. Neurosci, 4 (1981) 419-461.

24 Moises, H C and Smith, C B., Changes in cortical adrenoceptor function following chronic morphine administration in rat, Soc Neuroscl Abstr., 9 (1984) 797

25 Morrison, J H , Grzanna, R., Molliver, M. and Coyle, $\mathrm{J} T$, The distribution and onentation of noradrenergic $\mathrm{f}_{1}$ bers in neocortex of the rat an immunofluorescence study, J Comp. Neurol , 181 (1978) 17-40.

26 Munson, P J. and Rodbard, D., LIGAND: a versatile computerized approach for characterization of ligand-binding systems, Anal Blochem, 107 (1980) 220-239

27 Olpe, H -R , Glatt, A, Laszlo, J. and Schellenberg, A., Some electrophysiological and pharmacological properties of the cortical, noradrenergic projection of the locus coeruleus in the rat. Brain Research, 186 (1980) 9-19

28 Parker, R B and Waud, D R., Pharmacological estımation of drug receptor dissociation constants. Statistical evaluation 1 Agonists, J Pharmacol Exp Ther, 177 (1971) $1-12$

29 Redmond, D E , Huang, Y H., Snyder, D R. and Maas, J W , Behavioral effects of stımulation of the nucleus locus coeruleus in the stump-talled monkey Macaca arctoides, Brain Research, 116 (1976) 502-510

30 Redmond, D E. and Huang, Y H , The primate locus coeruleus and effects of clonidine on opiate withdrawal, $J$ Clin. Psychiat , 43 (1982) 25-29

31 Resnick, R.B , Kestenbaum, R S , Schwartz, L K and Smith, A , Evaluation of propranolol in opiate dependence, Arch. Gen Psychiat, 33 (1976) 993-997

32 Roth, R H , Elsworth, J D and Redmond, D E., Clondine suppression of noradrenergic hyperactivity during morphine withdrawal by clonidine biochemical studies in rodents and primates, $J$ Clin Psychiat, 43 (1982) 42-46

33 Satoh, M, Zieglgansberger, W and Herz, A , Interaction between morphine and putative excitatory neurotransmitters in cortical neurones in naive and tolerant rats, $\mathrm{Llfe} S \mathrm{Sc}$, 17 (1975) $75-80$

34 Schultz, J E , Siggins, G R , Schocker, F W , Turck, M and Bloom, F E , Effects of prolonged treatment with lith1um and tricyclic antidepressants on discharge frequency, norepinephrine responses and $\beta$-receptor binding in rat cerebellum electrophysiological and biochemical compar1son, J Pharmacol Exp. Ther, 216 (1981) 28-38

35 Stone, T W and Taylor, D A . Microiontophoretic studies of the effects of cyclic nucleotides on excitability of neurons in the rat cerebral cortex, $J$ Physiol (London), 266 (1977) 523-543

36 Wang, R Y and Aghajanian, G K., Inhibition of neurons in the amygdala by dorsal raphe stımulation mediation through a direct serotonergic pathway. Brain Research, 120 (1977) 85-102

37 Waterhouse, B.D., Lin, C -S , Burne, R A. and Woodward. D.J , The distribution of neocortical projection neu- 
rons in the locus coeruleus, $J$ Comp Neurol. 217 (1983) $418-431$

38 Waterhouse, B D. Molses, H C, Yeh. H H and Woodward. D J , Norepınephrıne enhancement of inhibitory synaptic mechanisms in cerebellum and cerebral cortex mediation by beta-adrenergic teceptors. $J$ Pharmucoi Exp Ther, 221 (1982) 485-506

39 Zerhe, $G O$. Archer, $P G$, Banchero, $N$ and Lechner A J , On comparing regression lines with unequal slopes, Am J Phislol, 242 (1982) R178-180 